\title{
The expenditure patterns of households receiving the State's Old- Age Pension (SOAP) grant in Kwakwatsi Township
}

\author{
TJ SEKHAMPU AND W GROBLER ${ }^{2}$
}

\begin{abstract}
The study on which this article is based investigated the expenditure patterns of households receiving the state's old-age pension grant. The old-age pension grant is the second-largest social grant in terms of the number of recipients and the largest when it comes to the monetary cost for the national government. The study looked at households in Kwakwatsi township receiving an old-age pension grant as the main source of income. The state's old-age pension grant is used only for sustenance, and for buying basic household necessities. Food is the biggest household expenditure for pension grant recipients. The pension grant is also used to support additional family members, thereby reducing its distributional impact. Households spend the grant mainly on products that support the daily functioning of the household.
\end{abstract}

Keywords: Social Grants, Poverty, Development Economics, Household Expenditure, Welfare Economics, Social Development, Household Income, Expenditure Patterns.

Disciplines: Economics, Poverty Studies, Development Studies, Policy Studies, Public Economics, Social Sciences, Health Sciences.

\section{Introduction}

Post-apartheid South Africa has achieved significant political transformation and incremental improvements in basic social services. At the same time, poverty and economic inequality have increased, making pro-poor socio-economic growth one of the greatest challenges facing South Africa (De Swardt, 2004). Over the past decade, the South African government has implemented numerous poverty-alleviation measures, with social assistance being one of them. The social assistance programme was not designed with specific exit strategies for beneficiaries, other than a change in their living circumstances and the income levels of recipients. Social assistance is a non-contributory system also called social grants, financed entirely from government revenue. The scheme is means-tested and the onus is on individuals to prove that they are destitute (SASSA, 2008).

There are currently five main types of social grant. The first is the State Old-Age Pension (SOAP), which provides support to men from the age of 62 and upwards, and to women aged 60 and upwards. The second is the Disability Grant (DG), which provides support to adults with disabilities. The third is the Child Support Grant (CSG), which provides support to families with children under the age of 15. The fourth is the Foster Child Grant, which provides support to families with children below the

1. Corresponding author: Dr TJ Sekhampu, Senior Lecturer, Economics, School of Economics, NorthWest University (Vaal), Joseph.sekhampu@nwu.ac.za, Tel: +27 169103408.

2. Dr W Grobler, Director, School of Economics, North-West University (Vaal), Wynand.grobler@nwu.ac.za Tel: +27 169103365. 
age of 18 in foster care. The fifth is the Care Dependency Grant, which provides additional support to families with children below the age of 18 with disabilities (Stats SA, 2009).

The effectiveness of South Africa's social security system, in terms of targeting and benefiting poor households, is widely recognised (Meth, 2002; Duflo, 2000). A number of complementary factors have contributed to this success. Duflo (2000) found significantly higher weight-for-height indicators for girls in households eligible for an old-age pension grant. Previous studies have also shown that households that receive pension grants have higher expenditure shares on food and education, and lower expenditure shares on alcohol, tobacco and entertainment than other households (Maitra and Ray, 2003). Social assistance through a direct transfer of national revenue to the vulnerable and needy has increased incrementally since 1994 and amounts to more than 3 per cent of the gross domestic product (GDP) (SASSA, 2008). South Africa is ranked as an upper-middle-income country based on average income, but some of the nation's social indicators are comparable to those of the poorest countries in the world. In this context of rooted poverty and unemployment, social grants have become an important source of income to millions of poor people (Samson et al., 2005). It is expected that the demand for social grants will continue to increase. This necessitates an investigation into how the grants are spent.

The purpose of the study on which this article is based was to investigate the expenditure patterns of households in the township of Kwakwatsi in the Free State province of South Africa receiving the state's old-age pension grant. The findings reported here are based on an empirical study conducted in Kwakwatsi. Information on households' expenditure forms an important part of the development planning process as such information can be used to prepare demand projections for social grants. The results of the study will assist the government in formulating policies to reduce poverty, inequality, diseases and malnutrition related to households receiving social grants.

The next section of the article provides justification for the study from a policy perspective. Thereafter the research methodology is outlined and the local community chosen for the analysis is discussed. The research findings are then presented and the article closes with a discussion on the findings of the study and the conclusions drawn.

\section{Policy Context of Social Grants}

A considerable number of the South African population live and work in urban areas, which are said to be growing at approximately 5 per cent per annum. This has resulted in the mushrooming of informal settlements in all major centres of the country (News 24,2008). After more than a decade of democracy, South Africa is still a country with high levels of poverty and income inequality (Larrson, 2006:6). The dysfunctional structure of South Africa's urban areas is an outcome of a number of factors, among them the now-defunct apartheid policy and associated planning approaches and economic forces, which have influenced city, town and township development for many years (Aliber, 2001:5).

The correct identification of the dynamics that perpetuate poverty and inequality, and the introduction of corrective policies have been singled out as priorities by both the government and civil society. The importance of reducing poverty and inequality has been a consistent theme of the postapartheid South Africa. Statements made by the government have recognised that all efforts need to be focused on the objectives of reducing poverty and inequality, and the barriers that limit participation in the economy.

In an attempt to alleviate the scourge of poverty, the South African government has adopted a multipronged approach, focusing on building institutions and organisations. At the heart of the povertyalleviation strategy has been the adoption of social assistance as a policy imperative (Galbraith, 2005). The argument is that social security is essential for healthy economic development, particularly in a 
rapidly changing economy, and will contribute actively to the development process (DOSD, 1997:53). The main objective of social security is to reduce poverty among groups that are not expected to participate fully in the labour market, and which are therefore vulnerable to low income: the elderly, those with disabilities and children. It also aims to increase investment in health, education and nutrition so as to increase economic growth and development (Samson et al., 2005).

Social security in South Africa has traditionally been characterised by a system of state social assistance in the form of direct cash transfers to poor people, the disabled, the elderly and a limited number of women and children (Lund, 2008). The system of social assistance for whites was started in the twentieth century. Social security for the elderly began with the Old-Age Pensions Act of 1928, which explicitly excluded most black South Africans. In 1937, a disability grant was extended on the same racial basis. In the late 1930s and 1940s, the social security system was broadened, but with racially differentiated benefit levels. Even by 1987, child support grants to blacks remained a small fraction of the size of those awarded to whites (Samson et al., 2005). The state's old-age pension was initially intended to provide a social safety net for the aged poor, who were vulnerable in the household because of a decline in job opportunities, increased vulnerability to poor health, limited mobility, discrimination in access to credit and financial markets, and changes in household composition and status (Harding, 1993).

After 1994 the new government was determined to eliminate any racial disparities in the allocation of social assistance. The aim was gradually to remove any racial discrimination at the level of benefits by rapidly increasing the amounts granted to African people, less rapidly increasing the amounts granted to Indian and coloured recipients, and letting whites' levels gradually erode (Lund, 2008). Section 27(1)(c) of the Constitution of South Africa states that everyone has the right to have access to social security. Those who are unable to support themselves and their dependants are entitled to appropriate social assistance (RSA, 1996). The Social Assistance Act (No. 59 of 1992) and the Social Security Agency Act (No. 9 of 2004) were signed into law. These acts provided for the establishment of the South African Social Security Agency (SASSA). The Social Assistance Act of 2004 defines the role of SASSA as that of ensuring the administration and payment of social assistance transfers to eligible poor and vulnerable adults and children (RSA, 2004).

The state's old-age pension grant is the second-largest social grant in terms of the number of recipients, but it is the largest grant when it comes to the monetary cost. The number of beneficiaries increased from 1.8 million in 2000 to 2.3 million in 2009. Consolidated expenditure on social protection has increased from R72.3 billion in 2005/06 (4.6 per cent of the GDP) to a projected R118.1 billion in 2009/10 (4.8 per cent of the GDP). In 2009/10, spending on the state's old-age pension grant is expected to be R28.5 billion (National Treasury, 2009).

The state's old-age pension grant plays an important role in old-age support systems through its potential to reach vulnerable individuals. Pension income helps to sustain households affected by extreme poverty and vulnerability, and facilitates economic and social development (Ardington and Lund, 1995). Case and Deaton (1998) conclude that the state's old-age pension is well targeted at the poorest households and households with children. In their study, Ardington and Lund (1995) found that pension income does reach poor households, does benefit the poorest children economically and does improve the health of all household members. Ferreira (2006) found that the vulnerability of households with one or more state old-age pension grant recipients was reduced by the pension benefits - there was greater financial stability and a lower probability of experiencing a decline in living standards in these households compared with those without pension income. The study also found a lower incidence of deprivation in households receiving pension grants than in non-pensioner households. 
The above studies have all concentrated on the impact of the pension grant on household income and on the probability of being poor. However, there is limited understanding of the dynamics of old-age pension grant recipients and their expenditure patterns. To obtain such information, a survey was undertaken to collect expenditure information from households in Kwakwatsi who rely on the state's old-age pension grant as their main source of income. The study, which is being reported here, provided a breakdown of the structures of households and their circumstances - information that can serve as a reference for further analysis and be utilised during policy development.

The population of Kwakwatsi is estimated at 15 095. The estimates are based on the municipality's integrated development plan. There are 3443 official residential sites, of which 3019 are occupied. Of the occupied sites, 1233 have permanent structures and 1786 have temporary structures or shacks. The area is a former black residential township located approximately $70 \mathrm{~km}$ south of Sasolburg and $280 \mathrm{~km}$ north of Bloemfontein in the Free State province of South Africa. The area is part of the Ngwathe Local Municipality, with its head office in Parys (Ngwathe Municipality, 2007).

\section{Research Methodology}

The aim of the study was to investigate the expenditure patterns of households in Kwakwatsi receiving the state's old-age pension grant. For the first stage of the study a survey was undertaken, based on the use of a questionnaire and personal interviews, in order to compile an economic profile of the township. Maps were obtained for the different areas of Kwakwatsi and a stratified sample was compiled by taking into account the geographical distribution and concentration of people in different areas of the township. The areas were divided into different extensions and the questionnaires were distributed evenly among the inhabited sites.

A total of 180 households were interviewed by two fieldworkers. All households approached were willing to take part in the study. To obtain a sample size that would supply statistically reliable results and be representative of the population of the area, the researcher relied on the experience and convention regarding similar surveys conducted in similar locations in South African townships (Slabbert \& Pelupessy, 2001). The second stage of the study involved follow-up interviews with the 80 households identified from the first stage of the research as being dependent on the state old-age pension grant as the main source of income. A second questionnaire was then developed to collect household expenditure information, providing the information on which this article is based. During this second phase of empirical work, the respondents were asked to list the items that they buy on a weekly or monthly basis. Both questionnaires included structural questions relating to demographic information and open-ended questions to capture the views of the respondents on their socioeconomic status.

The reliability of the results depended on the ability of the respondents to provide accurate information and not what they think the interviewer would like to hear. To address this problem, two trained fieldworkers were used. They had to emphasise to the respondents the importance of providing accurate information. The covering letter attached to the questionnaire explained the rationale of the study and the importance of co-operation from each household. Contact details were also provided on the covering letter in case the respondents doubted the credibility of the fieldworkers. Ethical clearance for the project was obtained beforehand from the Research Ethics Committee of the Faculty of Economic and Management Sciences of the North-West University.

\section{Empirical Results}

This section presents the findings of the study. The information obtained is at household level and is meant to the trends among receivers of the state's old-age pension grants. First the demographic information is described, followed by a discussion on the expenditure patterns of the sample population. 


\section{Demographics}

The demographic information affords an understanding of the household structures of the sample population. The classification of the population from different angles could be a reflective measure of the area's resources and of the availability and distribution of such resources. These demographics form an important part of the government's development mandate since households provide the labour for the production of goods and services, and also consume the final output of production. In addition, the size of a particular population is an important determinant of the socio-economic needs of the population (DBSA, 2006). The results of the study showed a high average household size (four) among households receiving the state's old-age pension grant in Kwakwatsi. This is in comparison with the average household size of three members for Ngwathe Municipality as a whole (Stats SA, 2007:81).

The majority ( 65.8 per cent) of the state's old-age pension grant recipients are female, and 34.2 per cent are male. Eighty per cent of the recipients of the grant are between the ages of 60 and 80 . A further investigation of the household structure of a typical household with a state old-age pensioner was undertaken. The gender distribution of the sample population showed that 46.5 per cent were males and 53.5 per cent females. Stats SA's (2009:4) midyear population estimates for Africans showed a national gender distribution of 48.3 per cent and 51.7 per cent for males and females respectively. For the Free State province, the gender distribution is 47.8 per cent males and 52.2 per cent females. Figures for Kwakwatsi therefore suggest a pattern similar to national figures.

Regarding the composition of households in terms of the status of members of the family, the survey results showed that 12.9 per cent of household members are fathers, compared with 21 per cent mothers. This indicates an increased likelihood of single parenting. The percentage of sons and daughters in the sample population was 16.4 per cent and 17.8 per cent, respectively. Further analysis shows that 23 per cent of the population falls into the category of "others", which was used to account for grandchildren and other household inhabitants (related or not). Table 1 shows an analysis of household composition.

\begin{tabular}{|l|r|r|}
\hline \multicolumn{3}{|c|}{ Table 1: Composition of households } \\
\hline & Frequency & Percentage \\
\hline Father/Husband & 37 & $12.9 \%$ \\
\hline Mother/Wife & 60 & $21.0 \%$ \\
\hline Son & 47 & $16.4 \%$ \\
\hline Daughter & 51 & $17.8 \%$ \\
\hline Grandfather & 3 & $1.0 \%$ \\
\hline Grandmother & 7 & $2.4 \%$ \\
\hline Uncle & 5 & $1.7 \%$ \\
\hline Aunt & 8 & $2.8 \%$ \\
\hline Other & 68 & $23.8 \%$ \\
\hline Total & 286 & $100.0 \%$ \\
\hline
\end{tabular}

Table 2 shows the age distribution of the sample population. Sixty per cent of the study population was 39 years and younger. Those who are eligible for the old-age grant accounted for 26.6 per cent of the sampled population. Lalthapersad-Pillay (2007) found that the old-age pension grant enables pensioners to support their extended family members, including grandchildren and unemployed adults. Access to the state's old-age pension grant is potentially a mitigating factor against vulnerability. The survey results confirm the importance of having an old-age pension grant recipient in the households. There was on average one old-age pension grant recipient per household. 


\begin{tabular}{|c|c|c|}
\hline \multicolumn{3}{|c|}{ Table 2: Age distribution of the population } \\
\hline Age & Frequency & Percentage \\
\hline $0-19$ & 97 & $33.9 \%$ \\
\hline $20-39$ & 75 & $26.2 \%$ \\
\hline $40-59$ & 38 & $13.3 \%$ \\
\hline $60+$ & 76 & $26.6 \%$ \\
\hline Total & 286 & $100.0 \%$ \\
\hline
\end{tabular}

Unemployment

The expanded definition of unemployment from Stats SA (2000) was used to determine the unemployment rate of the households. The unemployed are defined as those people within the economically active population who did not work during the seven days prior to the interview, and who want to work and were available to start within a week of the interview. The results showed an unemployment rate of 84.8 per cent. Furthermore, only 72 per cent of the unemployed were, at that stage, actively looking for a job, with the rest of the unemployed having given up due to limited employment opportunities. The greatest proportion of those who had given up on finding employment were those over the age of 40 ( 65 per cent). The cost of searching for employment due to the location of the township in relation to other industrial towns was also cited as a deterrent to searching for employment.

Unemployment has significant economic and social costs for individuals and households, as well as for the larger society. Unemployment and the inability to earn a regular income are the main reasons why people end up in poverty and also why it becomes difficult to move out of poverty (Larsson, 2006:4). In these households unemployment has a gender bias, as 52 per cent of the unemployed are females. Table 3 shows the unemployed in terms of age categories.

\begin{tabular}{|c|r|r|}
\hline \multicolumn{5}{|c|}{ Table 3: Unemployment by age categories } \\
\hline Age & Frequency & Percentage \\
\hline $15-20$ & $10 \%$ & $9 \%$ \\
\hline $21-25$ & $25 \%$ & $23 \%$ \\
\hline $26-30$ & $23 \%$ & $21 \%$ \\
\hline $31-35$ & $10 \%$ & $14 \%$ \\
\hline $36-40$ & $5 \%$ & $12 \%$ \\
\hline $41-45$ & $3 \%$ & $2 \%$ \\
\hline $46-50$ & $11 \%$ & $9 \%$ \\
\hline $51-55$ & $5 \%$ & $7 \%$ \\
\hline $56-60$ & $5 \%$ & $3 \%$ \\
\hline $61-65$ & $3 \%$ & $0 \%$ \\
\hline & $100 \%$ & $100 \%$ \\
\hline
\end{tabular}

Sources of household income

The respondents were asked about their sources of household income and these are shown in Figure 1. The state's old-age pension grant makes up 68.9 per cent of the household income in the sample population. The second highest contributor is salaries at 10.8 per cent. The child support grant also plays an important role as it contributes 10.8 per cent to household income. If added together, government grants make up 88.9 per cent of household incomes in the sample population. This confirms the importance of government grants in maintaining the livelihood of many South African households. The average household income is calculated at R1 504.70 per month. 


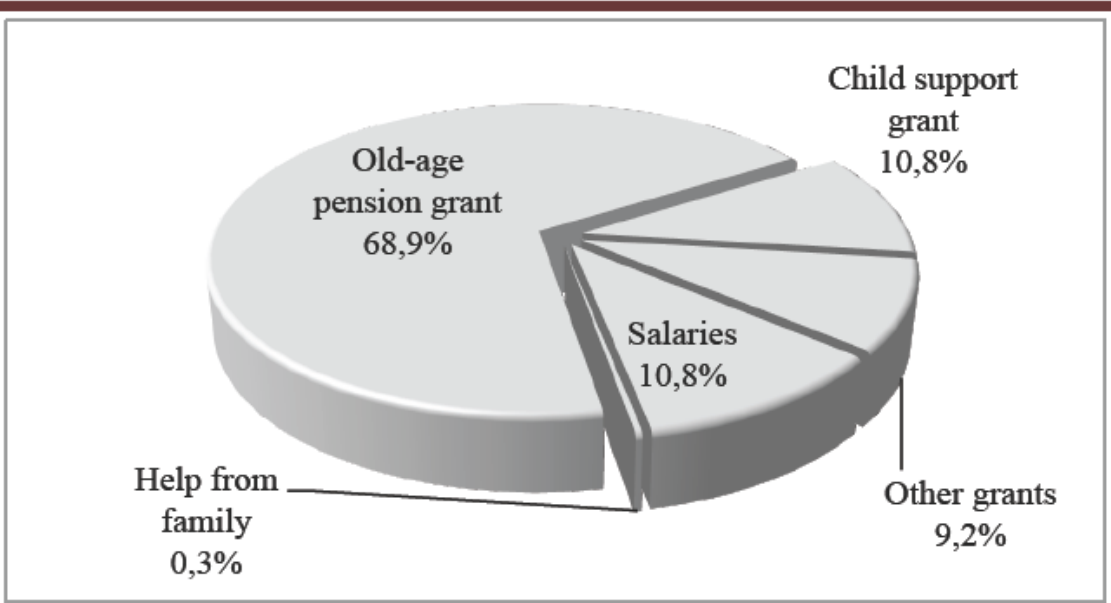

Figure 1: Sources of household income

Expenditure patterns of households

The items on which households spend their grants were measured in terms of the amount spent in relation to income over the period of a month. Food represented the single largest expense, accounting for 32.3 per cent of total monthly expenses (see Table 4). National income and expenditure survey results for 2005/2006 show that the poorest 20 per cent of households allocate a considerably higher proportion of their expenditure to food and non-alcoholic beverages, clothing and footwear than the richest 20 per cent of households. The former allocate approximately 37 per cent of their consumption expenditure to food and non-alcoholic beverages, while the latter allocate approximately 10 per cent to these (Stats SA, 2008:15).

\begin{tabular}{|l|r|r|}
\hline \multicolumn{3}{|c|}{ Table 4: Expenditure patterns of households receiving the SOAP } \\
\hline & Mean & Contribution \\
\hline Water & R40.00 & $2.8 \%$ \\
\hline Electricity & $\mathrm{R} 67.26$ & $4.7 \%$ \\
\hline Other energy & $\mathrm{R} 72.53$ & $5.1 \%$ \\
\hline Food & $\mathrm{R} 459.40$ & $32.3 \%$ \\
\hline Cigarettes and tobacco & $\mathrm{R} 46.77$ & $3.3 \%$ \\
\hline Beer, wine and spirits & $\mathrm{R} 66.25$ & $4.7 \%$ \\
\hline Transport & $\mathrm{R} 31.86$ & $2.2 \%$ \\
\hline Clothing & $\mathrm{R} 40.00$ & $2.8 \%$ \\
\hline School & $\mathrm{R} 28.50$ & $2.0 \%$ \\
\hline Entertainment & $\mathrm{R} 35.00$ & $2.5 \%$ \\
\hline Medical expenses & $\mathrm{R} 41.38$ & $2.9 \%$ \\
\hline Insurance & $\mathrm{R} 77.25$ & $5.4 \%$ \\
\hline Gambling & $\mathrm{R} 36.00$ & $2.5 \%$ \\
\hline Savings & $\mathrm{R} 50.00$ & $3.5 \%$ \\
\hline Licences (e.g. TV) & $\mathrm{R} 4.64$ & $0.3 \%$ \\
\hline Housekeeping services (e.g. garden) & $\mathrm{R} 62.50$ & $4.4 \%$ \\
\hline Telecommunication & $\mathrm{R} 44.25$ & $3.1 \%$ \\
\hline Furniture & $\mathrm{R} 100.00$ & $7.0 \%$ \\
\hline Other & $\mathrm{R} 119.00$ & $8.4 \%$ \\
\hline Total & $\mathrm{R} 1422.59$ & $100.0 \%$ \\
\hline
\end{tabular}

A study by the Economic Policy Research Institute (EPRI) (2004) associated social grants with an increased allocation of spending in a manner that supports better nutrition. According to that study, 
households that were receiving social grants had significantly different spending patterns from similar households that do not receive these grants. These households spend a greater proportion of their income on basic necessities such as food, fuel, housing and household operations than non-recipients.

The commonest form of insurance reported by households is funeral scheme-based insurance, for which a household makes a monthly contribution to an undertaker in order to receive burial benefits upon the death of the insured, and a small cash amount for funeral expenses. The respondents felt the need to have funeral insurance so as to avoid the burden of burial costs in the event of their death or that of a family member. Electricity expenditure amounted to 4.7 per cent of household expenditure. Electricity, coal and wood (or other energy sources) are used in combination. Although these households use coal/wood for cooking and heating the house, all of them had electricity connections and used electricity primarily for lighting.

An interesting point to note is that 7 per cent of the income was used to pay for furniture. This is for payment on lay-by schemes, whereby household items are paid for while still in the possession of the furniture store. This payment plan carries little risk for the store owner as the goods remain in his/her possession until the final payment has been made. In addition, some households use the services of a domestic helper for doing laundry and basic chores on a part-time basis, mainly for age and health reasons. This expenditure amounts to an average of 4.4 per cent of monthly household expenditure.

The main needs reiterated by households were food and money for daily sustenance. The majority of respondents (72.7 per cent) said the grant did not cover their needs. All respondents complained of the rapid increase in prices due to the economic downturn and wished that the grants could be increased. When asked about the monetary amount by which the grants should be increased, an average amount of R400 per month was recorded. Despite the fact that the overall grant does not cover the basic needs of all households entirely, 55.8 per cent of the sample population appreciated the fact that they receive an income with which they can support their families. With regard to lending, the respondents said that they could not borrow money as they do not have any security. The use of money lenders was not prevalent as households said that it was not common practice in the area.

\begin{tabular}{|l|c|c|c|}
\hline \multicolumn{4}{|c|}{ Table 5: Expenditure on food items } \\
\hline & Mean & $\begin{array}{c}\text { \% of the } \\
\text { grant }\end{array}$ & \% of household income \\
\hline Maize meal & R114.53 & $11.3 \%$ & $7.6 \%$ \\
\hline Bread & R40.94 & $4.1 \%$ & $2.7 \%$ \\
\hline $\begin{array}{l}\text { Meat and } \\
\text { chicken }\end{array}$ & R67.84 & $6.7 \%$ & $4.5 \%$ \\
\hline Vegetables & R35.69 & $3.5 \%$ & $2.4 \%$ \\
\hline Milk & R28.79 & $2.9 \%$ & $1.9 \%$ \\
\hline Other food items & R141.56 & $14.0 \%$ & $9.4 \%$ \\
\hline Total & R420.35 & $42.5 \%$ & $28.5 \%$ \\
\hline
\end{tabular}

A further analysis of the food items bought showed that each household consumes, on average, a $30 \mathrm{~kg}$ bag of maize (mealie) meal per month. Maize meal is the staple food of these households and its cost amounts to about 11.3 per cent of the current pension payout of R1 010 per person. The breakdown of the expenditure on items under the category of food is shown in Table 5. The households also buy meat, with an average expenditure on this item of R67.84 per month. A typical combination of meat bought is $2 \mathrm{~kg}$ of frozen chicken during the pension payout week and thereafter weekly meat cuts (insides, liver, etc.) of lower quality bought at the local convenience stores. 


\section{Lessons from the State's Old-Age Pension Grant recipients}

Previous studies on the distributional effect of social grants showed that they are effective in addressing the problem of hunger, as well as basic needs in general. Spending in households that receive social grants focuses more on basics such as food, fuel, housing and household operations, and less on tobacco and debt payment. Households that receive social grants have lower prevalence rates of hunger in young children as well as in older children and adults, even compared with those households with comparable income levels (DOSD, 2004). The respondents were asked about their survival strategies and whether they are able to sustain themselves on the pension grant. The majority of respondents (72.7 per cent) said that the pension grant is not large enough to cater for all their household needs, and that they hoped it would be increased by R400. Most of the households (68 per cent) said that they consider themselves poor, but 32 per cent said that they do not consider themselves poor. Deaton (1997:5) cautions against overemphasising the approach of asking people how they view their socio-economic status against tested tools of measurement, pointing out that there are cases where someone's own assessment of his/her own standard of living could be misleading. This is because an element of judgement is involved in answering the question of whether one considers oneself poor or not. These respondents may not feel socially excluded and hence their response.

In an attempt to extend the financial reach of the grants, households prefer to buy the hampers sold on pension pay-out days. A hamper is a combination of basic necessities sold together and is said to be cheaper than buying the items individually. A hamper can include flour $(2 \mathrm{~kg})$, sugar $(2 \mathrm{~kg})$, vegetables $(5 \mathrm{~kg})$, tea/coffee $(200 \mathrm{~g})$, cooking oil $(2 \mathrm{\ell})$ and washing powder $(2.5 \mathrm{~kg})$. A number of the sample population (34 per cent) said that they eat porridge (maize meal) as it is cheaper, and 32 per cent said that they buy only the major supplies (see Table 6). The lack of food security of many of the households was evident when they were asked whether they normally have three meals a day: 30 per cent said that they cannot afford to have three meals a day and that they are able to have only two meals a day (breakfast and supper), due to increased food prices. The common tradition is to have porridge as part of every meal session. Some families have gone as far as frying the porridge with animal fat to make it more edible. A study by Van Driel (2009) found the daily staple of social grant earners to be "pap" (maize meal porridge) for breakfast, black tea and a piece of bread for lunch, and pap again for supper. During the week, people eat this porridge (savoury) with spinach and potatoes. When money allows, the diet includes chicken feet, pork bones, eggs and sour milk.

\begin{tabular}{|l|r|r|}
\hline \multicolumn{3}{|c|}{ Table 6: Coping strategies of the sample population } \\
\hline & Frequency & Percentage \\
\hline Buy major supplies & 25 & $32.5 \%$ \\
\hline Get help from family and friends & 4 & $5.2 \%$ \\
\hline Eat porridge & 26 & $33.8 \%$ \\
\hline Hunt for bargains & 4 & $5.2 \%$ \\
\hline Maintain a vegetable garden & 4 & $5.2 \%$ \\
\hline Receive food parcels & 1 & $1.3 \%$ \\
\hline Buy on credit & 1 & $1.3 \%$ \\
\hline Buy in bulk & 5 & $6.5 \%$ \\
\hline Stick to budget & 7 & $9.0 \%$ \\
\hline Total & 77 & $100 \%$ \\
\hline
\end{tabular}

TD, 7(1), July 2011, pp. 41- 52. 
A small percentage of the population (1.3 per cent) said that they buy some items on credit from local convenience stores. They stated that it is easier to get household items on credit as store owners rely on the fact that a pension grant recipient's remittance is guaranteed. Family members also offer assistance to 5.2 per cent of the households. Some respondents said that they have family members working in big cities who sporadically send them money. Other households (5.2 per cent) said that they maintain a small backyard vegetable garden where they can plant some basic vegetables. These include onions, cabbage and wild spinach ("morogo"), which they can eat with their porridge if they run out of options. Table 6 lists all the responses to the question on the coping strategies employed by households. Households are stuck in a daily struggle to ensure that the old-age pension grant serves the needs of the family. The common thread was limited sources of income, the inability to earn income due to age, high unemployment and the difficulty of providing for the needs of the family from the old-age pension grant.

The state's old-age pension grant plays an important role in the sustenance of many households. It does not, however, cover much more than the basic survival needs of these households. The expenditure patterns of the households suggest an increase in the proportion of the grant spent on the overall needs of the different members of each household. Household expenditure is skewed towards products that support the daily functioning of the household, namely food and energy.

\section{Conclusions}

The main aim of the study on which this article is based was to investigate the expenditure patterns of households in Kwakwatsi township in the Free State receiving the state's old-age pension grant as the main source of income. The old-age pension grant is used mainly for the maintenance of the household on a day-to-day basis. The households have limited options on what to spend their income due to the need for subsistence. Many of the recipients of pension grants have the added burden of taking on the role of caregiver to other household members as a result of the high rate of unemployment. The expenditure items of these households show that the pension grant is used as a survival income, mainly for basic household items, and that 32.3 per cent of the grant is used to buy food. Different mechanisms are employed to alleviate the burden of increased prices. The pension grant forms an integral part of the government's development mandate and assists in reducing hunger and malnutrition among the poor. The increased average household size of pension grant recipients and the age distribution of members of these households show that pension income reaches poor households, benefits children economically and has the potential to improve the health of all household members. The old-age pension grant enables pensioners to support their extended family members, including grandchildren and unemployed adults.

Further research could focus on:

- The need to incorporate other social assistance programmes with the state's old-age pension grant and an assessment of its overall impact on the level of household spending

- The potential impact of giving additional assistance to pension grant recipients in the form of food vouchers to relieve them of the burden of increased spending on basic necessities; this could be based on a national guideline on staple foods for pension grant recipients

- The viability of targeted small-scale programmes aimed at assisting female household members based on their skills (the majority of members in these households are female)

- The potential impact of the death of a pension grant recipient on the socio-economic indicators of households containing such a member

The state's old-age pension grant plays an important role in the sustenance of many households. However, the grant does not serve the needs of the members beyond basic survival. The expenditure patterns of the households surveyed suggest increased spending of the grant on the overall needs of 
different members in each household. Household expenditure is mostly on products that support the daily functioning of the household, such as food and energy costs.

\section{References}

Alcock, P., 1997. Understanding poverty, second edition. London: Macmillan Press.

Aliber, M., 2001. Study of the incidence and nature of chronic poverty and development policy in South Africa: an overview. Pretoria: Southern African Regional Poverty Network.

Ardington, E. \& Lund, F., 1995. Pensions and development: social security as complementary to programmes of reconstruction and development. Development Southern Africa, 12.

Case, A. \& Deaton, A., 1998. Large-scale transfers to the elderly in South Africa. Economic Journal, 108.

DBSA (Development Bank of Southern Africa), 2006. Regional socio-economic analysis. Midrand: DBSA.

Deaton, A., 1997. The analysis of household surveys: micro-economic approach to development policy. Princeton, NJ: Princeton University.

De Swardt, C., 2004. Cape Town's African poor. Programme for Land and Agrarian Studies. Cape Town: University of the Western Cape.

DOSD (Department of Social Development), 1997. White Paper on Social Welfare. Pretoria: DOSD.

Duflo, E. 2000. Grandmothers and granddaughters: Old Age Pension and intra-household allocation in South Africa. National Bureau of Economic Research Working Paper No. 8061.

EPRI (Economic Policy Research Institute), 2004. The social and economic impact of South Africa's social security system. Pretoria: Government Printer.

Ferreira, M., 2006. The differential impact of social pension income on household poverty alleviation in three South African ethnic groups. London: Cambridge University Press.

Galbraith, J.K., 2002. A perfect crime: global inequality. Daedalus, 1(1): 12-25.

Harding, A. (ed), 1993. Micro-simulation and public policy. Selected papers from the IARIW Special Conference on Micro-simulation and Public Policy, Canberra, 5-9 December 1993.

Larsson, A., 2006. Government response to poverty and unemployment in South Africa: a micro-level evaluation of the expanded public works programme. Bachelor's Thesis, Sweden: Uppsala University.

Lalthapersad-Pillay, P., 2007. The poverty alleviation impetus of the social security system in South Africa. Africa Insight, (37):4.

Lund, F., 2008. Changing social policy: the child support grant in South Africa. Cape Town: HSRC Press.

Maitra, P. \& Ray, R., 2003. The effect of transfers on household expenditure patterns and poverty in South Africa. Journal of Development Economics, 71(1): 23-49. 
Meth, C., 2002. Poverty relief through social grants in South Africa: Is there an alternative? Paper presented at the DPRU Conference, 22-24 October 2002, Johannesburg.

National Treasury, 2009. The 2009 budget review. Pretoria: Government Printer.

News 24, 2008. Urbanisation a big problem.

http://www.news24.com/Content/SouthAfrica/News/1059/e44a0f7ebef948a380d500c7af5aa81f/2508-2008-06-04/Urbanisation_a_big_problem.

Ngwathe Local Municipality, 2007. Integrated Development Plan 2007-2012. Parys: Ngwathe Municipality.

RSA (Republic of South Africa), 1996. Constitution of the Republic of South Africa, (Act No. 108 of 1996). Pretoria: Government Printer.

RSA (Republic of South Africa) Ministry for Welfare and Population Development, 1997. White Paper on Social Welfare, Vol. 386 (No. 18166), Pretoria: Government Printer.

RSA (Republic of South Africa), 2004. South African Social Security Agency Act (No. 9 of 2004). Pretoria: Government Printer.

Samson, M., Lee U., Ndlebe, A., Quene, K.M., Van Niekerk, I., Gandgi, V., Harigaya, T. \& Abrahams, C., 2004. The social and economic impact of South Africa's social security system. Pretoria: Government Printer.

Samson, M., MacQueen, K. \& Van Niekerk, I., 2005. Social grants - Policy Brief 1. London: Overseas Development Institute.

SASSA (South African Social Security Agency), 2006. Linking social grants beneficiaries to poverty alleviation and economic activity. Pretoria: Government Printer.

SASSA (South African Social Security Agency), 2008. Strategic plan 2008/09-2010/11. Pretoria: Government Printer.

Slabbert, T.J.C. \& Pelupessy, W., 2001. Towards employment generation in South African townships: a case of Emfuleni Municipality Area. Africa Insight, 31(4): 35-42.

Stats SA see Statistics South Africa

Statistics South Africa, 2000. October household survey. Statistical release P0137, Pretoria: Government Printer.

Statistics South Africa, 2007. Community survey 2007. Statistical release P0301, Pretoria: Government Printer.

Statistics South Africa, 2008. Income and expenditure of households. Statistical release P0100, Pretoria: Government Printer.

Statistics South Africa, 2009. Social grants: in-depth analysis of the General Household Survey data 20032007. GHS Series Vol. 1, Pretoria: Government printer.

Van Driel, M., 2009. The social grants and black women in South Africa: a case of Bophelong Township in Gauteng. Journal of International Women's Studies, 10(4). 